\title{
THE UTILISATION OF THE PRODUCT LIFE CYCLE CONCEPT IN SOUTH AFRICAN BANKS DEALING WITH MORTGAGE PRODUCTS AND MARKETS
}

\author{
FJ Herbst, University of Johannesburg \\ M Steyn, University of Pretoria
}

\begin{abstract}
The purpose of the study as demarcated in this article was to test the use of the product life cycle concept (PLC) theory among marketing decision-makers and product decision-makers dealing with mortgage products and markets in the leading South African Banks. The main focus was to test the application and likelihood to use the PLC assumptions provided by Kotler (2003:340) on marketing characteristics, described marketing objectives and the proposed marketing strategies in the four PLC phases.

A major finding was that the majority of these decision-makers in banks indicated a high likelihood of continuing to use the product life cycle concept. Another important conclusion of this study was that further empirical research is needed to develop product life cycle concept assumptions to be inclusive of the intangible nature linked to the marketing of services.
\end{abstract}

Key words: marketing decisions, product decisions and product life cycle

\section{INTRODUCTION}

The product life cycle concept (PLC) depicts sales over time and it is a relatively good predictor of sales behaviour in certain market situations, but there are however certain questions pertaining to its practical applicability.

Various writers in the academic and in the business press have however questioned the product life cycle concept (Dhalla \& Yuspeh, 1976; Thorelli \& Burnett, 1981; Midgley, 1981; Sproles, 1981; Tellis \& Crawford, 1981; Mercer, 1993 and Grantham, 1999). There are furthermore different arguments against the application of the product life cycle concept as a marketing instrument in the current dynamic environment.

The application of the product life cycle concept for marketing decision-making has been tested in mainly large organisations around the globe. It is evident from the literature that the product life cycle concept has been applied to many situations ranging from the manufacturing industry to financial management (Rink, 1976; Ayal, 1981; Harrel \& Taylor, 1981; Qualls, Olshavsky \& Michaels, 1981; Thorelli \& Burnett, 1981; Tigert \& Farivar, 1981; Birou, Fawcett \& Magnan, 1998; Grantham, 1999; Rink, Roden \& Fox, 1999; Magnan, Fawcett \& Birou, 1999 and Shankar, Carpenter \& Krishnamaruthi, 1999).

The empirical part of this study as demarcated in this article investigated the utilisation of the PLC assumptions - marketing characteristics, marketing objectives and marketing strategies as described by Kotler (2000: 316) and constantly referred to as Kotler's theory.

\section{RESEARCH PROBLEM}

The objective of this study was to suggest that the PLC concept has been left behind by product developers in the financial institution realm and specifically more so in developing products for the 
low, middle and higher class of mortgage up-takers. Although Herbst, (2001:12-15) has questioned the utilisation of the PLC concept in product development for FMCG and industrial markets, research on this topic for service markets lacks in significant proportion.

Consequently, the following research problem was formulated: Do South African banks utilise the traditional and currently existing PLC concept in product development?

\section{RESEARCH OBJECTIVES}

The primary objective of this study was to establish what the use and practical value of the PLC is in product development decisions in retail banking in South Africa, concentrating on mortgage bonds.

The secondary objectives for this study were:

(a) To determine the driving forces behind mortgage product development.

(b) To establish the importance of the application of the PLC in the execution of marketing aspects.

(c) To determine whether the PLC concept is applied on each individual product within each product range.

(d) To investigate the ability of banks to describe the position of sales, profits and costs in each phase of the PLC.

(e) To establish if banks know in which phase their primary products or product range is positioned.

(f) To determine the level of influence the PLC concept has on product development.

(g) To investigate the ability of banks to identify PLC characteristics as depicted by marketing literature.

(h) To investigate the ability of banks to identify product development and PLC characteristics in accordance with marketing theory.

(i) To investigate the ability of banks to link marketing mix elements with the PLC concept.

(j) To determine the degree of control banks have over the 7 marketing mix instruments.

Due to this article's length restriction, Kotler's (2003:340) theory will be provided in Table format as part of the results section in paragraph 5 .

\section{RESEARCH DESIGN AND METHODOLOGY}

A research design is the plan to be followed to realise the research objectives or hypotheses (Tustin, Ligthelm, Martins \& Van Wyk, 2005:83). A research design depicts the design as detailing the procedure necessary for obtaining the required information; with the purpose of the design of a study being to test hypotheses or propositions of interest, determine possible answers to the research and provide the information needed for decision-making.

\section{Sampling}

Sampling decisions are often complex, although probability and non-probability sample categories are available (Cooper and Emory, 1995:202). The sampling method selected depends on the requirements of the specific project, its objectives and available funds.

A simple random sample (probability sampling method) of $52(n=52)$ was employed during this research in order to draw a representative sample of 13 banking staff operating in mortgage product development areas in each of the four major retail banks in South Africa. The units of 
analysis (respondents) had to be part of the mortgage product development or mortgage product management teams and completed a self-administered questionnaire, as delivered to the administrator (in all cases the Head of Product Development). A cover sheet with a message was attached to the questionnaires, explaining the purpose of the study.

\section{Questionnaire design}

The principle of questionnaire design was applied and the questionnaire was developed from the literature (Dillon, Madden and Firtle, 1993:379-383). Pre-testing was done according to the industry standard and the final questionnaire consisted of 12 pages, including 17 open-andclosed-ended questions, and was divided into four distinct sections (A-D):

\section{- Introduction and explanation of the key concepts used in the study}

- Section A: Profile information

- Section B: $\quad$ Specific product life cycle (PLC) questions

- Section C: $\quad$ PLC related to product development, planning and the marketing mix instruments (7Ps)

- Section D: $\quad$ The importance of the marketing mix instruments, PLC characteristics and strategies linked to the different phases of the PLC

For the purposes of the closed-ended questions, both 4-point scales and a 5-point Likert scale were used. The scale values were labelled from "not important at all"/"unsure", indicated by a scale value of 1 , to "extremely important", indicated by a scale value of 4 and 5 .

\section{Data analysis}

The data was captured in Microsoft Excel and exported to SPSS for data processing purposes.

The researcher used descriptive statistics, frequency distributions, top-box scores and low-box scores to report the results. Cross tabulations were used on variables to compare results while ttests were employed to determine whether significant differences exist. Content validity was utilised to indicate that the measurements used captured the characteristics of interest. The content of the measures in the questionnaire originated from previous studies reported in the literature review and was regarded to be sufficient to address the objectives of this study formulated in chapter one.

The following research propositions were formulated and tested:

$\mathbf{P}_{1}$ : South African banks focus more on competitor leads (duplication of existing competitor products) for product development, than on utilising the PLC concept (following each stage as indication of next steps for development).

$\mathbf{P}_{2}$ : South African banks are more concerned about the application of the product life cycle concept for pricing than any other marketing function.

$\mathbf{P}_{3}$ : South African banks will start and /or continue to apply and use the product life cycle concept for product decision-making purposes.

$\mathbf{P}_{4}$ : There is a difference in what South African banks believe the position (high or low) of sales, profits and costs are in each phase of the product life cycle in comparison to Kotler's theory.

$\mathbf{P}_{5}$ : There is a difference between Kotler's theory and South African banks' match for characteristics per product life cycle phase including the product development phase.

$\mathbf{P}_{6}$ : There is a difference between Kotler's theory and South African banks' match in strategies for each product life cycle phase. 


\section{RESULTS AND PROPOSITIONS}

\section{The realisation rate}

The fieldwork was conducted mainly in Johannesburg, as all 4 major South African Banks operate from their Head Offices within Johannesburg. Each bank received 13 questionnaires for completion and 49 of the 52 questionnaires were completed. Thus, an overall realisation rate of $94.2 \%(49 / 52)$ was achieved.

\section{Representativeness of the results}

Although the realised sample was representative of the product development community within mortgage markets and the sampling elements were randomly selected within each of the 4 banks, the results achieved during this study are only representative of the relevant banks and their Head Office environments.

\section{Results on a question-by-question basis}

Due to the length restriction, the results reported in this article will be limited and linked to the support and/or non-support of the formulated propositions. These questions are 5.1, 5.2, 6.1, 12, $13,14,15,16$ and 17.

\section{Results on Questions 5.1 and 5.2 linked to question 1}

Question 5.1: Please indicate the importance of utilising the following sources and /or changes in the environment as drivers for product development within your Bank.

Greater profit with a mean value of 3.67 was ranked as the most important driver of product development followed by competitors (3.60) and consumer changes (3.59). Academic research (2.57), international benchmarking (2.73) and employee-driven ideas (2.84) were ranked as the least important drivers of product development.

Question 5.2: Please indicate the three most important drivers for product development in your Bank.

Greater profit with a frequency of $19.05 \%$ was indicated as the most important driver for product development in the bank, followed by competitors (17.69\%) and consumer changes $(12.93 \%)$. Academic research with a frequency of $0.68 \%$ was confirmed to be the least important driver for product development followed by "Other" (that includes service, customer needs and change) (1.36\%), followed by employee-driven ideas (2.04\%).

\section{Proposition 1 was supported by the empirical results from questions 5.1 and 5.2.}

\section{Results on questions $6.1,12$ and 16 linked to proposition 2}

\section{Question 6.1:}

How important is the application of the product life cycle concept in the execution of the following aspects of your Bank?

Pricing was regarded as the most important aspect when applying the product life cycle concept, 
with a mean score of 3.57 and a top-box score of $67.35 \%$. Pricing was followed by product development and costing, with mean scores of 3.48 and 3.35 and top-box scores of $57.14 \%$ and $51.02 \%$ respectively. A standard deviation of 0.67 for pricing was the lowest of all aspects. It can consequently be concluded that the respondents were the most homogenous on the importance of pricing as an aspect in the application of the PLC.

Question 12: How important is each of the following aspects (the $4 \mathrm{Ps}$ ) when associated with the four phases of the product life cycle?

Marketing decision-makers in banks had to rate the importance of marketing mix- related aspects of product, price, place and promotion in each product life cycle phase. The mean scores on all four marketing mix instruments are depicted in Table 1.

Table 1: Importance of the traditional marketing mix-related aspects

\begin{tabular}{|l|c|}
\hline \multicolumn{1}{|c|}{ Marketing mix instrument } & Mean \\
\hline Product & 3.55 \\
\hline Price & 3.54 \\
\hline Place & 3.50 \\
\hline Promotion & 3.08 \\
\hline
\end{tabular}

It is evident from Table 1 that product is regarded as the most important traditional marketing mix instrument with a mean score of 3.55. The mean scores on the other three marketing mix instruments were lower than 4, but higher than the average mean value of 3 . The different mean scores on the four marketing mix instruments, that typify the importance of marketing mix instruments in the different PLC phases for the sample, are illustrated in Table 2.

Table 2: $\quad$ The importance of the marketing mix instruments in the different PLC phases

\begin{tabular}{|c|l|c|c|}
\hline $\begin{array}{c}\text { Marketing mix } \\
\text { instrument }\end{array}$ & \multicolumn{1}{|c|}{ PLC phase } & Mean & Standard deviation \\
\hline \multirow{4}{*}{ Product } & Introductory & 4.31 & 0.65 \\
\cline { 2 - 4 } & Growth & 4.20 & 0.62 \\
\cline { 2 - 4 } & Maturity & 3.92 & 0.77 \\
\cline { 2 - 4 } & Decline & 3.41 & 0.89 \\
\hline \multirow{5}{*}{ Price } & Introductory & 3.55 & 0.62 \\
\cline { 2 - 4 } & Growth & 3.54 & 0.58 \\
\cline { 2 - 4 } & Maturity & 3.51 & 0.71 \\
\cline { 2 - 4 } & Decline & 3.07 & 0.88 \\
\hline \multirow{5}{*}{ Place } & Introductory & 4.26 & 0.61 \\
\cline { 2 - 4 } & Growth & 4.27 & 0.62 \\
\cline { 2 - 4 } & Maturity & 4.16 & 0.65 \\
\cline { 2 - 4 } & Decline & 3.57 & 0.92 \\
\hline \multirow{5}{*}{ Promotion } & Introductory & 4.61 & 0.46 \\
\cline { 2 - 4 } & Growth & $\mathbf{4 . 4 0}$ & 0.54 \\
\cline { 2 - 4 } & Maturity & 3.67 & 0.79 \\
\cline { 2 - 4 } & Decline & $\mathbf{2 . 7 4}$ & 1.14 \\
\hline
\end{tabular}

The mean values depicted in Table 2 are indicative of the high importance placed on all the 
marketing mix instruments in the PLC phases except for promotion (2.74) in the decline phase. By comparing the mean scores per PLC phase depicted in Table 2, it can be deduced that: promotion is the most important marketing mix instrument in the introductory (4.61) and growth (4.40) phases; product is the most important marketing mix instrument in the maturity (3.92) phase; and place is the most important marketing mix instrument in the decline phase (3.57).

Table 3 reveals whether there are significant differences between the mean values of the marketing mix instruments in the different PLC phases.

Table 3: $\quad$ Significance test on the importance of the marketing mix instruments in the different PLC phases

\begin{tabular}{|c|c|c|c|c|c|c|c|c|}
\hline \multirow[b]{3}{*}{ PLC phases } & \multicolumn{8}{|c|}{ Marketing mix instruments } \\
\hline & \multicolumn{2}{|c|}{ Product } & \multicolumn{2}{|c|}{ Price } & \multicolumn{2}{|c|}{ Place } & \multicolumn{2}{|c|}{ Promotion } \\
\hline & Mean & $\begin{array}{l}\text { Standard } \\
\text { deviation }\end{array}$ & Mean & $\begin{array}{l}\text { Standard } \\
\text { deviation }\end{array}$ & Mean & $\begin{array}{l}\text { Standard } \\
\text { deviation }\end{array}$ & Mean & $\begin{array}{l}\text { Standard } \\
\text { deviation }\end{array}$ \\
\hline $\begin{array}{l}\text { Introductory } \\
\text { phase }\end{array}$ & 4.31 & 0.65 & a) 3.55 & 0.62 & 4.27 & 0.62 & b) 4.61 & 0.46 \\
\hline $\begin{array}{l}\text { Growth } \\
\text { phase }\end{array}$ & 4.20 & 0.62 & c) 3.54 & 0.58 & 4.27 & 0.62 & d) 4.40 & 0.54 \\
\hline $\begin{array}{l}\text { Maturity } \\
\text { phase }\end{array}$ & 3.92 & 0.77 & e) 3.51 & 0.71 & f) 4.16 & 0.65 & 3.67 & 0.79 \\
\hline $\begin{array}{l}\text { Decline } \\
\text { phase }\end{array}$ & 3.41 & 0.89 & 3.08 & 0.88 & h) 3.57 & 0.92 & g) 2.74 & 1.14 \\
\hline
\end{tabular}

Note: Significant differences on mean values indicated by different superscripts ${ }^{\text {a) }}$ to ${ }^{\text {h) }}$ in the different PLC phases $(p \leq 0.05)$

A Friedman two-way analysis of variance for non-parametric statistics was used to compare the mean scores on the importance of the different marketing mix instruments in the different marketing mix phases. The test for significant differences in Table 3 illustrates significant differences between the marketing mix instruments in the introductory, growth, maturity and decline phases.

Question 16: How important is each of the following aspects (the additional 3 Ps) when associated with the four phases of the product life cycle?

Respondents (marketing decision-makers) in banks rate the importance of the marketing mixrelated aspects of people, processes and physical evidence within each product life cycle phase. (In question 12 marketing decision-makers had the opportunity to rate the importance of marketing mix related aspects on product, price, place and promotion within each product life cycle phase). Armed with the results on questions 12 and 16, the researcher was able to develop marketing mix-related aspects that can be associated with each PLC phase.

All the marketing mix-related aspects pertaining to processes, people, and physical evidence were important, except for the marketing mix aspects linked to people in the decline phase, which showed a lesser importance.

Table 4 provides a summary of the mean values per marketing mix instrument. 
Table 4: $\quad$ Importance of marketing mix instruments

Q12 $\left\{\begin{array}{|l|c|c|}\hline \text { Marketing mix instrument } & \text { Mean } & \text { p-value } \\ \hline \text { Product } & 3.96 & \mathbf{0 . 0 0 0 0} \\ \hline \text { Price } & 3.42 & \mathbf{0 . 0 0 8 3} \\ \hline \text { Place } & 4.07 & \mathbf{0 . 0 0 0 0} \\ \hline \text { Promotion } & 3.86 & \mathbf{0 . 0 0 0 0} \\ \hline \text { People } & 4.11 & \mathbf{0 . 0 0 0 0} \\ \hline \text { Processes } & 4.29 & \mathbf{0 . 0 0 8 3} \\ \hline \text { Physical evidence } & \mathbf{4 . 5 1} & \mathbf{0 . 0 0 0 0} \\ \hline\end{array}\right.$

It can be deduced from Table 4 that all the marketing mix instruments were regarded as important based on the average mean scores depicted. A Friedman non-parametric one-way ANOVA test was employed to determine whether the importance (mean values) of the different marketing mix instruments are significant or not. As illustrated in Table 8, there are significant differences in the importance of product $(0.0000)$, price $(0.0083)$, place $(0.0000)$, promotion (0.0000), people $(0.0000)$, processes $(0.0083)$ and physical evidence $(0.0000)$, as the $p$-values are $\leq 0.05$.

The significant differences on all seven marketing mix instruments, as depicted in Table 4, can be indicative of the difference in importance of each marketing mix instrument in the different PLC phases.

Proposition 2 can be supported by the empirical results from questions 6.1, 12, and 16.

Results on question 14 linked to proposition 3

Question 14: What is the likelihood that your Bank will start, continue or stop using the product life cycle concept in future for (a) general decision-making and (b) product decision-making?

The likelihood that marketing decision-makers in banks will start, continue or stop using the product life cycle concept for general management and product decision-making purposes in future is an important indicator of the utilisation potential and value of the product life cycle concept. Tables 5 and 6 provide an indication of the likelihood that marketing decision-makers in the sample will start, continue or stop using the product life cycle in future for general and product decision-making purposes respectively.

Table 5: $\quad$ Likelihood of starting, continuing or stopping the use of the product life cycle in future for general management decision-making

\begin{tabular}{|l|c|c|c|c|}
\hline $\begin{array}{c}\text { Extent of } \\
\text { influence }\end{array}$ & Frequency & Percentage & $\begin{array}{c}\text { Cumulative } \\
\text { frequency }\end{array}$ & $\begin{array}{c}\text { Cumulative } \\
\text { percentage }\end{array}$ \\
\hline Start using & 21 & $42.86 \%$ & 21 & $\mathbf{4 2 . 8 6 \%}$ \\
\hline Continue using & 26 & $\mathbf{5 3 . 0 6 \%}$ & 47 & $95.92 \%$ \\
\hline Stop using & 2 & $4.08 \%$ & 49 & $100.00 \%$ \\
\hline TOTAL & $\mathrm{N}=\mathbf{4 9}$ & $\mathbf{1 0 0 \%}$ & - & - \\
\hline
\end{tabular}

A majority of $53.06 \%$ of the respondents indicated (a scale value of 2 ) the likelihood of the continued use of the product life cycle for general management decision-making in future as depicted in Table 5. This result provides a positive indication that the product life cycle concept 
has a continuous usage potential among banks for general management decision-making purposes in future. It can also be noted that the sample indicated that general management decision-making would start to use the product life cycle concept $(42.86 \%)$.

Table 6 depicts the likelihood of decision-makers in banks to start, continue or stop using the product life cycle concept for product decision-making purposes in future.

Table 6: Likelihood of starting, continuing or stopping the use of the product life cycle concept for future product decision-making

\begin{tabular}{|l|c|c|c|c|}
\hline $\begin{array}{c}\text { Extent of } \\
\text { influence }\end{array}$ & Frequency & Percentage & $\begin{array}{c}\text { Cumulative } \\
\text { frequency }\end{array}$ & $\begin{array}{c}\text { Cumulative } \\
\text { percentage }\end{array}$ \\
\hline Start using & 15 & $\mathbf{3 0 . 6 1 \%}$ & 15 & $30.61 \%$ \\
\hline Continue using & 33 & $\mathbf{6 7 . 3 5 \%}$ & 48 & $97.96 \%$ \\
\hline Stop using & 1 & $2.04 \%$ & 49 & $100.00 \%$ \\
\hline TOTAL & 49 & $\mathbf{1 0 0 . 0 0 \%}$ & - & - \\
\hline
\end{tabular}

A majority of $67.35 \%$ of the marketing decision-makers in banks indicated a high likelihood of continuing to use the product life cycle concept for product decision-making in future, as illustrated in Table 6 . It should also be noted that $30.61 \%$ of the sample responded that it would start using the product life cycle for product decision-making in future.

\section{Proposition 3 can be supported by the empirical results from questions 14.}

\section{Results on question 13 linked to proposition 4}

Question 13: Please indicate the position (high or low) of the following elements in the different stages of the product life cycle.

Question 13 provided marketing decision-makers in banks the opportunity to link the position of sales, profits and costs in each phase of the PLC concept, by indicating a high or low position for each element in each phase. The data was then compared to Kotler's (2003:340) theory on the position of sales, profits and costs in each phase of the product life cycle.

Table 7 depicts the frequency of high and low positions for each element in each phase of the product life cycle. The highest frequencies per element and phase are highlighted.

Table 7: $\quad$ Frequency distribution of high and low positioning of sales, profits and expenses per product life cycle phase

\begin{tabular}{|l|c|c|c|c|}
\hline \multicolumn{1}{|c|}{ PLC phase } & Position & Sales & Profits & Expenses \\
\hline \multirow{2}{*}{ Introductory phase } & High & 21 & 12 & 4 \\
\cline { 2 - 5 } & Low & $\mathbf{2 8}$ & $\mathbf{3 7}$ & $\mathbf{4 5}$ \\
\hline \multirow{2}{*}{ Growth phase } & High & $\mathbf{4 2}$ & $\mathbf{3 1}$ & $\mathbf{3 3}$ \\
\cline { 2 - 5 } & Low & 7 & 18 & 16 \\
\hline \multirow{2}{*}{ Maturity phase } & High & $\mathbf{4 2}$ & $\mathbf{4 5}$ & 13 \\
\cline { 2 - 5 } & Low & 7 & 4 & $\mathbf{3 6}$ \\
\hline \multirow{2}{*}{ Decline phase } & High & 7 & 24 & 20 \\
\cline { 2 - 5 } & Low & $\mathbf{4 2}$ & $\mathbf{2 5}$ & $\mathbf{2 9}$ \\
\hline
\end{tabular}


No conclusions, other than frequency counting, can be derived from Table 7 . The frequencies depicted in Table 8 can be compared to the theory provided by Kotler (2003:340).

Table 8: $\quad$ Frequency distribution of the sample linking the theory on the positioning of sales, profits and expenses in each of the PLC phases

\begin{tabular}{|l|c|c|c|c|}
\hline \multicolumn{1}{|c|}{ PLC phase } & Position & Sales & Profits & Expenses \\
\hline \multirow{2}{*}{ Introductory phase } & High & - & - & B \\
\cline { 2 - 5 } & Low & a & a & T \\
\hline \multirow{2}{*}{ Growth phase } & High & b & a & A \\
\cline { 2 - 5 } & Low & T & - & - \\
\hline \multirow{2}{*}{ Maturity phase } & High & a & a & - \\
\cline { 2 - 5 } & Low & - & - & A \\
\hline \multirow{2}{*}{ Decline phase } & High & T & - & - \\
\cline { 2 - 5 } & Low & b & a & A \\
\hline
\end{tabular}

Note: $T=$ Appropriate positioning of elements according to Kotler's theory in the different PLC phases; $a$ = Highest frequency was reported from respondents and this coincide with Kotler's theory; and $b=$ Highest frequency was reported from respondents and this is incorrect according to Kotler's theory.

Table 8 indicates a linkage success rate of $75 \%(9 / 12 \times 100)$ as indicated by (a). The best linkage was achieved with the positioning of sales, profits and expenses of $100 \%(3 / 3)$ in the maturity phase, as the other three phases all had one position incorrect - a $66 \%$ linkage.

\section{The findings indicate that proposition 4 cannot be conclusively supported.}

\section{Results on question 15 linked to proposition 5}

Question 15: Please match the following characteristics in Column A to the most appropriate phase in Column B by means of a tick mark next to the word or description in Column A. Please note that a characteristic in Column A can appear in one or more of the phases in column B.

The main objective with question 15 was to determine whether organisations differed from or matched the theory on marketing characteristics associated with the various product life cycle phases according to Kotler's theory (2003:340). It is important to note that the researcher included the product development phase according to the theory by Hisrich \& Peters (1991:49). Table 9 provides a frequency of the sample.

The total frequency for each characteristic associated with the different PLC phases is reflected in Table 9 and the highest frequency of each characteristic is highlighted. To illustrate: project management reported the highest total frequency of 43 in the development phase. The total frequencies depicted in Table 9 above seem to be high, but a characteristic could have appeared in more than one PLC phase. 
Table 9: Frequency distribution of the total sample with regards to the characteristics in each of the PLC phases

\begin{tabular}{|l|c|c|c|c|c|}
\hline \multicolumn{1}{|c|}{ Characteristic } & \multicolumn{4}{|c|}{ Phases in PLC per group } \\
\cline { 2 - 6 } & $\begin{array}{l}\text { Developmen } \\
\mathbf{t}\end{array}$ & $\begin{array}{c}\text { Introducto } \\
\text { ry }\end{array}$ & $\begin{array}{c}\text { Growt } \\
\mathbf{h}\end{array}$ & $\begin{array}{c}\text { Maturit } \\
\mathbf{y}\end{array}$ & $\begin{array}{c}\text { Declin } \\
\text { e }\end{array}$ \\
\hline Project Management & $\mathbf{4 3}$ & 40 & 38 & 13 & 12 \\
\hline Low sales & 12 & 29 & 9 & 3 & $\mathbf{3 3}$ \\
\hline Peak sales & 1 & 4 & 25 & $\mathbf{3 7}$ & 4 \\
\hline Screening & $\mathbf{3 9}$ & 27 & 7 & 9 & 12 \\
\hline High profits & 1 & 7 & 23 & $\mathbf{4 0}$ & 9 \\
\hline Increasing profits & 1 & 12 & $\mathbf{3 8}$ & 13 & 4 \\
\hline Major expenses & 41 & $\mathbf{4 2}$ & 9 & 3 & 10 \\
\hline Increasing sales & 4 & 15 & $\mathbf{4 2}$ & 13 & 2 \\
\hline High cost per customer & 16 & $\mathbf{3 6}$ & 12 & 3 & 23 \\
\hline Average cost per customer & 3 & 7 & 19 & $\mathbf{2 8}$ & 7 \\
\hline $\begin{array}{l}\text { Number of competitors beginning } \\
\text { to decline }\end{array}$ & 3 & & & & \\
\hline R \& D & $\mathbf{4 5}$ & 24 & 10 & 9 & 17 \\
\hline Low cost per customer & 1 & 4 & 7 & $\mathbf{3 5}$ & 16 \\
\hline Declining sales & 0 & 1 & 2 & 14 & $\mathbf{4 7}$ \\
\hline Losses & 14 & $\mathbf{2 8}$ & 8 & 5 & 31 \\
\hline Declining profits & 0 & 1 & 3 & 13 & $\mathbf{4 6}$ \\
\hline Declining number of competitors & 2 & 2 & 8 & 18 & $\mathbf{3 8}$ \\
\hline Pricing strategy & $\mathbf{4 0}$ & 35 & 21 & 25 & 14 \\
\hline Few competitors & 22 & $\mathbf{2 7}$ & 11 & 4 & 24 \\
\hline Competitive advantage & 29 & $\mathbf{3 2}$ & 21 & 16 & 8 \\
\hline
\end{tabular}

All the highest frequencies as depicted in Table 9 were used to compile Table 10, indicating the highest frequencies achieved for each characteristic in each PLC phase for the sample. This result was then compared to the theory provided by Kotler (2003:340); and Hisrich \& Peters (1991:49).

Table 10 provides a comparison between the responses of the sample and the theory from Kotler and Hisrich \& Peters. Kotler's theory was applied to the introduction, growth, maturity and decline phases, while Hisrich \& Peters's theory was applied to the product development phase. These two components will be discussed separately.

It is evident from Table 10 that the sample concurred with $78.5 \%(11 / 14 \times 100)$ of the characteristics in the phases in the product life cycle according to the theory provided by Kotler (2003:340). The sample concurred with $66.66 \%$ (4 / $6 \times 100)$ of the characteristics in the product development phase according to the theory provided by and Hisrich \& Peters (1991:49).

The respondents had the highest frequency for low sales in the decline phase of the PLC indicated by an (b) in Table 10. This can be an indication of possible confusion by the respondents on the difference between low sales and declining sales. 
Table 10: Comparison of the total sample's responses of characteristics with the theory in each of the PLC phases

\begin{tabular}{|c|c|c|c|c|c|c|}
\hline \multirow{2}{*}{\multicolumn{2}{|c|}{ Characteristics }} & \multicolumn{5}{|c|}{ PLC phases } \\
\hline & & $\begin{array}{c}\text { Developmen } \\
\text { t phase }\end{array}$ & $\begin{array}{l}\text { Intro } \\
\text { phase }\end{array}$ & $\begin{array}{l}\text { Growth } \\
\text { phase }\end{array}$ & $\begin{array}{l}\text { Maturity } \\
\text { phase }\end{array}$ & $\begin{array}{c}\text { Decline } \\
\text { phase }\end{array}$ \\
\hline \multirow{4}{*}{$\frac{\mathscr{d}}{\mathscr{N}}$} & Low sales & & $\mathrm{T}$ & & & b \\
\hline & Peak sales & & & & a & \\
\hline & Increasing sales & & & a & & \\
\hline & Declining sales & & & & & a \\
\hline \multirow{3}{*}{ है } & High cost per customer & & $\mathbf{a}$ & & & \\
\hline & $\begin{array}{l}\text { Average cost per } \\
\text { customer }\end{array}$ & & & $T$ & b & \\
\hline & Low cost per customer & & & & a & \\
\hline \multirow{4}{*}{$\frac{0}{\frac{0}{5}}$} & High profits & & & & $\bar{a}$ & \\
\hline & Increasing profits & & & $a$ & & \\
\hline & Losses & & a & & & \\
\hline & Declining profits & & & & & a \\
\hline \multirow{3}{*}{ 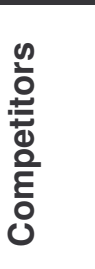 } & $\begin{array}{l}\text { Number of } \\
\text { competitors beginning to } \\
\text { decline }\end{array}$ & & & & $\mathbf{T}$ & b \\
\hline & $\begin{array}{l}\text { Declining } \\
\text { number of competitors }\end{array}$ & & & & & a \\
\hline & Few competitors & & a & & & \\
\hline \multirow{6}{*}{ 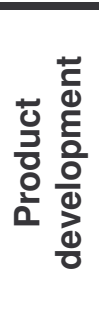 } & Project management & a & & & & \\
\hline & Screening & $\mathbf{A}$ & & & & \\
\hline & Major expenses & $T$ & b & & & \\
\hline & $R \& D$ & $\mathbf{A}$ & & & & \\
\hline & Pricing strategy & $\mathbf{A}$ & & & & \\
\hline & Competitive advantage & $\mathbf{T}$ & b & & & \\
\hline
\end{tabular}

Note: $a=A$ perfect association of the sample with theory on the characteristic in the specific PLC phase

$b=\quad$ No association of the sample with the theory on the characteristic in the specific PLC phase

$T=\quad$ Kotler's theory (2003:340); Hisrich \& Peters' theory (1991:49)

The respondents achieved a $78.5 \%$ match with the characteristics in each product life cycle phase as provided by theory (Kotler, 2003:340). The respondents furthermore achieved a $66.6 \%$ match with the characteristics in the product development phase as provided by theory (Hisrich \& Peters, 1991:49).

The findings indicate that the characteristic assumptions in proposition 5 cannot be supported.

\section{Results on question 17}


Question 17: Please link the following strategies in Column A to the most appropriate phase in Column B with a tick mark next to the strategy in Column A.

Respondents were given the opportunity to link the strategies in the different product life cycle phases to the strategies provided in the theory (Kotler, 2003:340). Table 11 illustrates the linkage with theory for the sample.

Table 11: Frequency distribution of the sample in linking the theory on the marketing strategies in each of the PLC phases

\begin{tabular}{|c|c|c|c|c|c|c|c|c|}
\hline \multirow{3}{*}{ Marketing strategies } & \multicolumn{8}{|c|}{ Product life cycle phases } \\
\hline & \multicolumn{2}{|c|}{$\begin{array}{l}\text { Introducto } \\
\text { ry phase }\end{array}$} & \multicolumn{2}{|c|}{$\begin{array}{c}\text { Growt } \\
\text { h } \\
\text { phase }\end{array}$} & \multicolumn{2}{|c|}{$\begin{array}{l}\text { Maturity } \\
\text { phase }\end{array}$} & \multicolumn{2}{|c|}{$\begin{array}{l}\text { Decline } \\
\text { phase }\end{array}$} \\
\hline & $\mathbf{T}$ & $\bar{Q}$ & $\mathrm{~T}$ & $\mathbf{Q}$ & $\mathbf{T}$ & $\bar{Q}$ & $\mathbf{T}$ & $\mathbf{Q}$ \\
\hline Diversify brands and models & & 17 & & 10 & $\sqrt{ }$ & 17 & & 5 \\
\hline Phasing out weak products & & 0 & & 2 & & 15 & $\sqrt{ }$ & 29 \\
\hline Cut prices & & 8 & & 16 & & 15 & $\sqrt{ }$ & 10 \\
\hline $\begin{array}{l}\text { Set a price to match or better the prices of } \\
\text { competitors }\end{array}$ & & 18 & & 19 & $\sqrt{ }$ & 11 & & 1 \\
\hline Set a price to penetrate the market & & 27 & $\sqrt{ }$ & 20 & & 0 & & 2 \\
\hline $\begin{array}{l}\text { Build awareness and interest in the mass } \\
\text { market through advertising }\end{array}$ & & 24 & $\sqrt{ }$ & 18 & & 7 & & 0 \\
\hline Build product awareness among early adopters & $\sqrt{ }$ & 35 & & 11 & & 1 & & 2 \\
\hline Increase and encourage brand switching & & 6 & & 27 & $\sqrt{ }$ & 13 & & 3 \\
\hline Use heavy sales promotion to entice trial & $\sqrt{ }$ & 26 & & 20 & & 2 & & 1 \\
\hline Build intensive distribution & & 18 & $\sqrt{ }$ & 28 & & 3 & & 0 \\
\hline Build selective distribution & $\sqrt{ }$ & 10 & & 5 & & 26 & & 8 \\
\hline Build more intensive distribution & & 5 & & 27 & $\sqrt{ }$ & 10 & & 6 \\
\hline $\begin{array}{l}\text { Offer product extensions, service and } \\
\text { guarantees }\end{array}$ & & 4 & $\sqrt{ }$ & 3 & & 32 & & 9 \\
\hline Charge a cost plus price & $\sqrt{ }$ & 15 & & 5 & & 15 & & 14 \\
\hline $\begin{array}{l}\text { Reduce the advertising level needed to retain } \\
\text { hard core loyal customers }\end{array}$ & & 2 & & 2 & & 30 & $\boldsymbol{v}$ & 15 \\
\hline Stress brand differences and benefits & & 10 & & 15 & $\sqrt{ }$ & 16 & & 8 \\
\hline Reduce sales promotion to the minimum levels & & 1 & & 1 & & 11 & $\sqrt{ }$ & 35 \\
\hline $\begin{array}{l}\text { Reduce sales promotion to take advantage of a } \\
\text { heavy consumer demand }\end{array}$ & & 1 & $\sqrt{ }$ & 20 & & 18 & & 9 \\
\hline $\begin{array}{l}\text { Go selective and phase out all unprofitable } \\
\text { outlets }\end{array}$ & & 3 & & 0 & & 16 & $\sqrt{ }$ & 30 \\
\hline
\end{tabular}

Note: $T \sqrt{ }=$ Appropriate marketing strategy according to Kotler's theory in the different PLC phases and $Q=$ the frequency

Marketing decision-makers were required to link the strategies in the different product life cycle phases to the strategies provided by Kotler (2003:340). The marketing strategies with the highest frequencies in each phase of the product life cycle are accentuated in Table 11.

Table 12 illustrates the comparison between the sample and Kotler's theory. 
Table 12: Comparison of the total sample response of marketing strategies in each of the PLC phases

\begin{tabular}{|c|c|c|c|c|c|}
\hline \multirow[b]{2}{*}{$\begin{array}{l}\text { Marketing } \\
\text { mix } \\
\text { instrument }\end{array}$} & \multirow[b]{2}{*}{ Strategies } & \multicolumn{4}{|c|}{ PLC phases } \\
\hline & & $\begin{array}{l}\text { Intro } \\
\text { phase }\end{array}$ & $\begin{array}{l}\text { Growt } \\
\text { h } \\
\text { phase }\end{array}$ & $\begin{array}{l}\text { Maturity } \\
\text { phase }\end{array}$ & $\begin{array}{l}\text { Declin } \\
\text { e } \\
\text { phase }\end{array}$ \\
\hline \multirow{3}{*}{ Product } & Diversify brands and models & & & $\mathbf{a}$ & \\
\hline & Phasing out weak products & & & & $\mathbf{a}$ \\
\hline & $\begin{array}{l}\text { Offer product extensions, service } \\
\text { and guarantees }\end{array}$ & & $T$ & b & \\
\hline \multirow{4}{*}{ Price } & Cut prices & & b & & $\mathbf{T}$ \\
\hline & $\begin{array}{l}\text { Set a price to match or better the } \\
\text { prices of } \\
\text { Competitors }\end{array}$ & & $\mathbf{b}$ & $\mathbf{T}$ & \\
\hline & Set a price to penetrate the market & b & $T$ & & \\
\hline & Charge a cost plus price & a & & & \\
\hline \multirow{4}{*}{ Advertising } & $\begin{array}{l}\text { Build awareness and interest in the } \\
\text { mass market through advertising }\end{array}$ & b & $\mathrm{T}$ & & \\
\hline & $\begin{array}{l}\text { Reduce the advertising level } \\
\text { needed to retain hard core loyal } \\
\text { customers }\end{array}$ & & & b & $\mathbf{T}$ \\
\hline & $\begin{array}{l}\text { Build product awareness among } \\
\text { early adopters }\end{array}$ & a & & & \\
\hline & $\begin{array}{l}\text { Stress brand differences and } \\
\text { benefits }\end{array}$ & & & a & \\
\hline \multirow{4}{*}{$\begin{array}{l}\text { Sales } \\
\text { Promotion }\end{array}$} & $\begin{array}{l}\text { Increase and encourage brand } \\
\text { switching }\end{array}$ & & $\mathbf{b}$ & $\mathbf{T}$ & \\
\hline & $\begin{array}{l}\text { Use heavy sales promotion to entice } \\
\text { trial }\end{array}$ & a & & & \\
\hline & $\begin{array}{l}\text { Reduce sales promotion to the } \\
\text { minimum levels }\end{array}$ & & & & a \\
\hline & $\begin{array}{l}\text { Reduce sales promotion to take } \\
\text { advantage of a heavy consumer } \\
\text { demand }\end{array}$ & & a & & \\
\hline \multirow{4}{*}{ Distribution } & Build intensive distribution & & a & & \\
\hline & Build selective distribution & $\mathbf{T}$ & & b & \\
\hline & Build more intensive distribution & & b & $\mathbf{T}$ & \\
\hline & $\begin{array}{l}\text { Go selective and phase out all } \\
\text { unprofitable outlets }\end{array}$ & & & & b \\
\hline
\end{tabular}

will enable the researcher to calculate a fit of the sample with the theory provided by Kotler (2003:340).

Table 12 indicates that the sample generated a linkage success rate of 52.63\% (10/19 $\times 100)$ as indicated by an (a). The sample achieved the best linkage with the strategies on sales promotion 
of $75 \%(3 / 4 \times 100)$ and the weakest linkage of $25 \%(1 / 4 \times 100)$ with strategies on price.

As depicted in Table 12 the sample:

- provided a $52.63 \%$ (10 / $19 \times 100)$ linkage with Kotler's theory on marketing strategies in each PLC phase;

- delivered the best linkage with the strategies on sales promotion with $75 \%$; and

- showed the weakest linkage with price strategies with $25 \%$ linkage.

The results demonstrated that marketing strategies as part of the assumptions in proposition 6 did differ considerably, although not substantially from Kotler's theory. As a result, this proposition cannot be supported.

It is important to realise that the support or non-support of the propositions in paragraphs 5.3.1 5.3.6 was done based on the following:

- $30.61 \%$ of all respondents have been in their positions longer than 2 years.

- $\quad 69.39 \%$ of all respondents have been in their positions between one month and two years. (This result is indicative of the dynamic environment of product development in which staff members are rotated on a regular basis).

- $30.61 \%$ of the respondents indicated that they occupy the function new product developer.

- $26.53 \%$ of the respondents indicated that their functions entail the project management of required systems and processes involved in product development and strategic and tactical marketing respectively.

\section{RECOMMENDATIONS FOR FUTURE RESEARCH}

Recommendations for future research will be based on recommendations for empirical research and literature as discussed below.

\section{Recommendations for future research on the application and use of the PLC concept}

The following are recommendations for future research on the application and the use of the product life cycle concept:

- A comparative study among all financial products (lending products, investment products, transactional products), by using the same methodology and measurement instrument, should be done to draw possible comparisons and to provide better clarity in the current debate on the practical application of the product life cycle concept.

- Empirical research on the product life cycle concept is necessary to enable financial institution staff globally to use the PLC concept as a foundation and guideline to improve decision-making.

- Current literature should be broadened through empirical research to assist South African decision-makers in financial institutions to accurately identify in which phase of the product life cycle their products or services are.

- Further empirical research is needed to develop a separate product life cycle concept for services to be inclusive of the intangible nature linked to the marketing of services.

- A replication study should be conducted in other service markets - car hire, hotel bookings, cellular service providers, etc.

\section{Recommendations based on the literature review}

The following are recommendations for possible future empirical research in reaction to current 
available literature of the application and use of the PLC concept:

- The researcher observed during the literature search that product development is often discussed as a completely different and removed topic from the product life cycle concept. Although the product development phase has a cycle of its own, it is recommended that the proximity between product development as a phase and the rest of the product life cycle phases are addressed.

- As a result of a fast-moving and ever-volatile market place, additions to the product life cycle concept such as: the financial product life cycle; the consumer life cycle; and the channel life cycle, can be addressed in new additions of marketing textbooks and future literature.

- The current literature on marketing strategies in the product life cycle phases needs to be revised to be inclusive of the intangible nature of the marketing of services.

- More literature is needed on the application of the product life cycle concept by decisionmakers in financial institutions globally, and in South Africa specifically.

- More literature is needed on the impact of the service component on the universal formulation of marketing objectives and marketing strategies by financial institutions.

- The current product life cycle concept literature needs to be revised to include a separate product life cycle concept theory for services marketing.

\section{CONCLUSION}

Product developers in the four leading South African banks indicated a high probability for utilising the traditional and currently existing PLC concept in the product development process of mortgage products.

Although the empirical results achieved by this study are only representative of the product development community within mortgage markets and the sampling elements, the following main conclusions can be drawn:

- Product developers in banks dealing with mortgage products tended to display a marketing knowledge level that was not in total unison with the existing marketing theory.

- There are still many unanswered questions and doubt about the product life cycle concept as a decision-making instrument.

- The current product life cycle concept theory needs to be broadened to include strategies on the expanded marketing mix (all 7Ps).

- The product life cycle concept theory has application potential as a strategic tool and there is a high likelihood for its use as a strategic product development and planning instrument in future.

\section{REFERENCES}

Ayal I. 1981. International product life cycle: A re-assessment and product policy implication. Journal of Marketing, Fall (45): 91-96.

Birou LM, Fawcett SE \& Magnan GM. 1998. The product life cycle: a tool for functional strategic alignment. International Journal of Purchasing and Materials Management, 34: 37-48.

Cooper DR \& Emory W. 1995. Business Research Methods. $5^{\text {th }}$ ed. USA: McGraw-Hill. 
Dhalla NK \& Yuspeh S. 1976. Forget the product life cycle concept. Harvard Business Review, January - February: 102-110.

Dillon WR, Madden TJ \& Firtle NH. 1993. Essentials of Marketing Research. Boston: Irwin INC.

Grantham LS. 1999. The validity of the product life cycle in the high-tech industry. Marketing Intelligence and Planning, 15(1): 4-10.

Harrell SG \& Taylor ED. 1981. Modelling the product life cycle for consumer durables. Journal of Marketing, (45): 68-75.

Hisrich RD \& Peters MP. 1991. Marketing Decisions for New and Mature Products. $2^{\text {nd }}$ ed. New York: Macmillan Publishing Company.

Herbst FJ. 2001. An investigation of the product life cycle concept as an instrument in marketing decision-making for selected small organisations in South Africa. Unpublished D.Com thesis. Pretoria: University of Pretoria.

Kotler P. 2003. Marketing Management. $11^{\text {th }}$ ed. New Jersey: Prentice Hall.

Magnan GM, Fawcett SE \& Birou LM. 1999. Benchmarking manufacturing practice by using the product life cycle. Benchmarking: An International Journal, 6(3): 239-253.

Mercer D. 1993. A two-decade test of product life cycle theory. British Journal of Management, 4(4), December: 269-274.

Midgley DF. 1981. Toward a Theory of the Product Life Cycle: Some Testable Propositions. Journal of Marketing, Fall (45): 109 - 115.

Qualls W, Olshavsky R \& Michaels RE. 1981. Shortening of the PLC - An empirical test. Journal of Marketing, Fall (45): 76-80.

Rink D. 1976. The product life cycle in formulating purchasing strategy. Industrial Marketing Management, August (5): 231-242.

Rink DR, Roden DM \& Fox HW. 1999. Financial management and planning with the product life cycle concept. Business Horizons, 42(5): 65-72.

Shankar V, Carpenter GS \& Krishnamurthi L. 1999. The advantages of entry in the growth stage of the product life cycle: an empirical analysis. Journal of Marketing Research, 36(2): 269276.

Sproles, GB. 1981. Analyzing Fashion Life Cycles: Principles and perspectives. Journal of Marketing, Fall (45): 116-124.

Tellis GJ \& Crawford CM. 1981. An evolutionary approach to product growth theory. Journal of Marketing, Fall (45): 125-132.

Tigert D \& Farivar B. 1981. The Bass new product growth model: A sensitivity analysis for a high technology product. Journal of Marketing, (45): 81-90. 
Thorelli HB \& Burnett SC. 1981. The nature of product life cycles for industrial goods businesses. Journal of Marketing, Fall (45): 97-108.

Tustin DH, Ligthelm AA, Martins JH and van Wyk HJ. 2005. Marketing Research in practice. $1^{\text {st }}$ ed. Pretoria: Unisa Press. 